\title{
Pedagogy and Learning Environment in a Franco-Ontarian Child Care Centre
}

\author{
ALAN D. RUSSETTE \\ Western University \\ SHELLEY KATHLEEN TAYLOR \\ Western University
}

\begin{abstract}
In order to succeed in French First Language (FFL) schools, students must have a working knowledge of French. For many Anglophone and Allophone students, the journey toward official bilingualism through FFL schooling begins in FFL child care centres. The programs offered in these centres were designed to foster the linguistic and literacy development of Franco-Ontarian children before they enter the FFL K-6 school system (CLR-Net, 2009; Government of Canada, 1982, 2008 \& 2012; Ministère de l'éducation, 2004; Ontario MEO, 2005). This paper investigates whether éducatrices in FFL child care centres can meet all children's French needs and, if so, how?
\end{abstract}

On the Canadian political, cultural, and economic landscape, French language education, whether first (L1) or second (L2) language, continues to be an important issue, as demonstrated by the Government of Canada's (2008) \$1.1 billion investment in the Roadmap for Canada's Linguistic Duality 2008-2013: Acting for the Future initiative. Emphasizing support for official language minority communities and (French-English) linguistic duality, the initiative funds L2 education programs and bursaries and supports French first language (FFL) education in official-language minority contexts (i.e., Francophone communities outside Quebec and New Brunswick) through family literacy programs and early childhood education and care (ECEC) (Government of Canada, 2008, 2012).

Increasingly, ECEC is a government concern because early literacy has been linked to higher adult literacy rates, which have in turn been linked to enhancing Canada's economic well-being by virtue of the competitive edge citizens with greater levels of literacy have in a knowledge society (Government of Alberta, 2009; Ontario Ministry of Education, 2005). The Canadian Language and Literacy Research Network's (2009) National Strategy for Early Literacy discusses increased societal literacy in terms of increased skills, while inadequate skills are seen as a societal expense. The Strategy also links inadequate skills to the need for sound literacy instruction in ECEC programs in French-language official language minority contextsi. It may be argued that funding provided to FFL family literacy programs and ECEC by the Government of Canada's (2008, 2012) Roadmap initiative is money well spent, not only economically (as an investment in Canada's economic future) and culturally/politically (in terms of linguistic duality and unity), but also in terms of linguistic rights (the right to L1 instruction). ${ }^{\text {ii }}$ 
Although French second language (FSL) programs, particularly French Immersion, had already been widely studied in Canada as early as the 1980s (Swain \& Lapkin, 1982), less research has focused on FFL education in official-language minority communities (though the research that has been conducted has had a considerable impact both nationally and internationally) (e.g., Gérin-Lajoie, 2003; Heller, 1999/2006). Heller's (1994/2003) work outlines the origins of the FFL school system in Ontario. The right of French linguistic minority populations to receive instruction in their own language in Canada was set out in Section 23 of the Canadian Charter of Rights and Freedoms (Government of Canada, 1982), while the Ontario Ministry of Education's (2004) French language policy was intended to ensure the protection, enhancement, and transmission of the French language and culture in minority settings. Yet a conundrum exists: the FFL educational system, which was developed to support language and literacy development in FFL children, is increasingly attracting official language majority and unofficial language minority children (Russette, 2013). Cormier, Bourque, and Jolicoeur (2014) noted that a similar situation exists in New Brunswick, where many children of Acadian (Francophone) heritage no longer speak French in the home, yet attend FFL schools. This study illustrates the complexities created by the presence of non-Francophone populations in a Franco-Ontarian child care centre in which children from FFL, English FL, and non-official minority FL backgrounds, like Spanish FL, are enrolled. The purpose of this study was to investigate the pedagogy employed and learning environment created in an FFL ECEC setting with multiethnic, multilingual educators and learners. This paper addresses the what, how, and why of the learning environment, and specifically how early childhood educators (or éducatrices) organized daily activities through the medium of French for the centre's young children and facilitated the children's learning and acquisition of the French language.

The results presented in this paper were derived from observation and participation in the day-to-day operations of a Franco-Ontarian child care centre over a ten-week period. Data collection methods included participant observation, interviews, and document analysis. As shown in the paper, the educators framed neither the learning environment nor the pedagogical approaches adopted in terms of FSL. Rather, by adopting an open-ended, child-directed, play-based "emergent curriculum" approach (Jones, 2012), they met the French language education (FLE) needs of all children in the program, regardless of their L1. The paper begins with a linguistic profile of FrancoOntarian Kindergarten to Grade 6 (K-6) schools and ECEC "feeder" centres, then presents select literature and theoretical considerations, methodology and context of the study, findings, discussion, and conclusion.

\section{Linguistic Profile of Franco-Ontarian \\ K-6 Schools and ECEC "Feeder" Centres}

FFL child care centres are gateways to the Franco-Ontarian school system and an important site of French language learning before children even step into the K-6 FFL system. While child care centres may be housed in K-6 schools in the Catholic or public FFL school boards, the centres are run independently. Information on the linguistic composition of FFL K-6 schools is more readily available to the public than that of 
ECEC centres; however, since the two sites are a continuation of each other, it is worth examining the linguistic background of children enrolled in Franco-Ontarian K-6 schools.

It should be noted that "Franco-Ontarian" refers to the Francophone population of Ontario that traces its ancestry back to the colony of New France. Although Francophone immigrants to Ontario are considered Franco-Ontarian, they made up only $14 \%$ of the Francophone population at the time of the 2006 Census (Office of Francophone Affairs \& The Ontario Trillium Foundation, 2009). The majority of Franco-Ontarians trace their ethnicity and culture back to the French colonies of North America.

In order to succeed in a FFL school, students must have a working knowledge of French. For many Anglophone and allophone students, the journey toward official bilingualism begins in FFL child care centres. While their programs were designed to lay the foundation for the linguistic and literacy development of Franco-Ontarian children when they enter the FFL school system (CLR-net, 2009; Government of Canada, 1982, 2008, 2012; Ministère de l'éducation, 2004; Ontario MEO, 2005), the question remains as to whether they also meet FL and literacy development needs of non-Francophone children? Additionally, if so, how? This paper investigates how the éducatrices in this FFL child care centre integrated educational activities and language instruction to facilitate the FL learning needs of their FSL learners.

\section{Select Literature and Theoretical Considerations}

The Francophone school systems in Southwestern Ontario are an interesting example of a minority group attempting to preserve its language and culture in the midst of a dominant linguistic and cultural community. They represent a concerted effort on the part of the minority group to valorize its cultural identity in the face of assimilation by the dominant language population. While exploring the roots of minority children's academic difficulties, Cummins $(1989,2001,2009)$ presents a theoretical framework of empowerment for minority students that pertains - and has been applied - to several alienated, disempowered minority groups, including Francophone children in official language minority settings in Canada (Cummins, 1997) as heightened cultural/linguistic diversity is characteristic of all educational settings in the West. ${ }^{\text {iii }}$ Of the four educational domains in which Cummins explores minority students' interactions with educators and societal institutions, his discussion of pedagogy is most pertinent to this case.

Cummins (1989) identifies two major orientations to pedagogy: transmission and interaction/experiential approaches. Transmission, as the name implies, is a passing of knowledge from teacher to student; this places the teacher in control of the information flow and lesson objectives. The interaction/experiential approach, by contrast, shifts the power away from the teacher and places more onus for learning on students. The Emergent Curriculum approach is an example of an interactive/experiential pedagogical model whose goal is to create learning opportunities for children that are rooted in their interests. To further explain the Emergent Curriculum and its link to interaction/experiential pedagogical approaches, Jones' (2012) description of it as openended, self-directed, related to intrinsic motivation, and appropriate for a play-based environment is of great relevance. While the Emergent Curriculum allows children to become architects of their own learning, children's interests are not the only curricular sources; teacher interests, the physical and social environment, and developmental tasks 
can also be sources of Emergent Curriculum (Jones, 2012), thus allowing teachers to seize "teachable moments" to facilitate children's learning. Jones states, "[t]o develop curriculum in depth, adults must notice children's questions and invent ways to extend them, document what happens, and invent more questions. The process is naturally individualized" (p. 67). This individualization of learning experiences is intended to develop children's strengths and passions and provide them with more meaningful knowledge than would be available through a more standardized, prescriptive (transmission) approach.

One way to assist L2 learners is through the use of gestures and a reliance on routines. Weber and Tardif (1990) suggest that language learning "is facilitated by the teacher's paralanguage (gestures, body movement, intonation, and expression) and by concrete materials, pictures, symbols, and rituals" (as cited in Taylor, 1992, p. 739). Rituals, in this context, refer to ongoing routines. They suggest that routines provide a framework for new linguistic elements and can scaffold meaning for children with no prior knowledge of French; similarly, an absence of routines limits their L2 learning (Taylor, 1998). Björklund, Mård-Miettinen, and Savijärvi (2014) note that "routines are natural contexts that offer more individual communication than many of the structured activities in large or small groups" (p. 199) and are ideal for L2 immersion environments. As will be discussed, the éducatrices in the FFL child care centre made significant use of routines and gestures, particularly with new arrivals to the centre.

While Cummins provides the backdrop for examining the centre as a whole, Lyster (2007) provides a more focused lens through which to understand and interpret how the Emergent Curriculum also frames classroom-based L2 learning and teaching. As shown above, while the mission of Franco-Ontarian schools in Southwestern Ontario is French first language instruction, they also constitute L2 learning environments for many children, given the linguistic make-up of the schools. As a result, many children experience content learning through their L2 in Franco-Ontarian schools and, as this study shows, in ECEC feeder settings as well. As such, Lyster's counterbalanced approach to teaching language through content is of relevance.

The key tenets of Lyster's (2007) Counterbalanced Approach to L2 Teaching are:

1. Instructional options that enable learners to engage with L2 learning through content (as opposed to traditional approaches that introduce grammar or vocabulary instruction first, for varying lengths of time (e.g., years), before introducing content instruction through the medium of the L2;

2. Language and cognitive development go hand-in-hand for young children, but traditional approaches to L2 teaching separate the two;

3. Content-based instruction is more motivational for children than, for instance, a focus on mechanical or metalinguistic aspects of L2 learning;

4. It is a "two for one" approach, with children learning both the L2 and content simultaneously;

5. Learning through content increases children's exposure to an L2;

6. It also increases opportunities for interaction throughout the course of purposeful L2 learning (pp. 1-2). 
However, he also notes that L2 development must be systematically planned because unplanned (or incidental) language teaching is inadequate to give children an understanding of new language structures.

The links between Lyster's (2007) Counterbalanced Approach to L2 learning and the Emergent Curriculum are not immediately evident in that his work has been associated with school-aged L2 learners. However, the two mesh well in one of the key tenets of his framework: language and cognitive development must go hand-in-hand for young children. Similarly, the Emergent Curriculum highlights play-based learning, that is, cognitive development through children's participation in purposeful activities geared towards accomplishing goals they set for themselves. Key to both pedagogical approaches are learner autonomy, engagement, and investment linked to meaningful activities appropriate to L2 learners' linguistic and cognitive development. Specifically, he argues that a counterbalanced instructional approach "integrates content-based and form-focused instructional options by interweaving balanced opportunities for input, production, and negotiation" (Lyster, 2008, p. 26) that make content comprehensible and language features salient. In Jones' (2012) terms, teachers seizing children's interests as a scaffold to further their cognitive development draws on their autonomy as learners; it allows children to become architects of their own learning. Just as ECEC instructors must adapt instruction to meet individual children's developmental needs, Lyster (2007, 2008) advises teachers to offer their students a range of intrinsically interesting opportunities to use the target language in the learning setting. Both the Emergent Curriculum and Lyster's $(2007 ; 2008)$ counterbalanced instructional approach are couched in terms of seizing teachable moments; this provides a framework for the data presented in this paper.

Lyster describes this approach as a systematic attempt at language instruction that requires learners to focus on content and target language features. He argues that for L2 students to develop native-like skills, they must receive "instruction that is counterbalanced in a way that more systematically integrates language and content" (p. 4). While FLE early childhood educators (ECEs) do not teach "content" the way elementary school teachers do with respect to specific subjects (e.g., social studies, mathematics, or drama), they nonetheless impart "content" appropriate to the guidelines for Early Childhood Education and Care as described in the ECEC framework, Early Learning for Every Child Today (Ontario Ministry of Children and Youth Services, 2007). ECEC "content" falls under several categories: social; emotional; communication, language and literacy; cognition; and physical domains of child development (Ontario Ministry of Children and Youth Services, 2007). The findings indicate the extent to which the FFL early childhood educators in this study integrated French teaching and content instruction and speak to the applicability of Lyster's (2007, 2008) Counterbalanced Approach in this Early Years context.

\section{Methodology, Context, and Participants}

This ten-week long, exploratory case study used document analysis (including ECEC framework documents and analysis of FFL child care websites) and ethnographic tools (participant observation; semi-structured interviews with three members of the child care staff and one parent; artefact collection; and photographic documentation). The site 
was determined by members of the ECEC centre's administration. They issued a memo to éducatrices requesting volunteers to participate in the study. The centre was identified on the basis of volunteers coming forward and timing (a new group of children was joining an existing preschool group). The centre that served as the research site featured a continual intake of new children, though the cap for each group was eight. To preserve anonymity, pseudonyms have been used for each participant.

Many non-Francophone children attended the child care centre (14 out of 16 fulltime children). Therefore, a considerable amount of pedagogical programming was aimed at welcoming new children into the FFL community and establishing a foundation for future learning in French. The first author observed the preschoolers three days per week from their arrival each day until afternoon nap time, a period that included a morning snack, free play times, lunch, and outdoor activities. The participants included five early childhood educators (éducatrices), one parent, and twelve preschool-aged children in a FLE child care centre in Southwestern Ontario. There were eighteen children in the preschool program; however, only twelve parents consented to participation in the study. An overview of the éducatrices' background and roles in the centre can be found in Table 1. The children came primarily from mixed race or minority backgrounds, but aside from two Francophone children and one bilingual child, the others were identified as "Anglophones" by the éducatrices, regardless of their ethnic background.

Table 1

Adult Participants

\begin{tabular}{|c|c|c|c|}
\hline Name & Role & $\begin{array}{c}\text { Dominant Language } \\
\text { (English/French/Other) }\end{array}$ & $\begin{array}{c}\text { Origin } \\
\text { (Canadian/Non-Canadian) }\end{array}$ \\
\hline Josie & $\begin{array}{c}\text { Toddler Room } \\
\text { Éducatrice/ } \\
\text { Supervisor }\end{array}$ & Other (Spanish) & Non-Canadian \\
\hline Monique & Éducatrice & French & Non-Canadian \\
\hline Karine & Éducatrice & French & Non-Canadian \\
\hline
\end{tabular}

Data collection and analysis were conducted inductively, particularly in the early stages of the case study, as the first author became more familiar with the centre's day-today routines. Descriptive field notes were recorded, assessed, and analyzed daily to adjust the focus for the next day's observations. From there, the focus was narrowed to particular children and éducatrices, paying attention to language-related events. Field notes were coded in a manner that allowed for potential trends or themes to emerge. Interviews were conducted at the end of the study and examined aurally in an effort to better understand the participants, their educational philosophies, and their perspectives on the children's progress. 


\section{Findings}

Data drawn from the first author's participant observations and interviews illustrate whether (and how) the éducatrices integrated educational activities and language instruction to facilitate the FFL and FSL children's French learning (Russette, 2013). The following descriptions of the roles played by routines, songs, and the "at the supermarket" activity in the children's French learning contextualize how the counterbalanced approach was merged with the Emergent Curriculum through "teachable moments" (Jones, 2012).

\section{The Role of Routines}

On the first day of participant observation, Josie ${ }^{\mathrm{iv}}$, supervisor and éducatrice for the toddler room, explained the toddler room routine to the first author and described the program philosophy as based on the "Emergent Curriculum" (which she referred to as "le nouveau programme" , in which teaching and learning opportunities are driven by child interests and explorations, rather than by adults dictating what children should do. She explained that her role was to observe and seek out opportunities to incorporate "teachable moments" into activities geared to individual children. For instance, if a child were playing with Lego building blocks, she would seize that opportunity to teach colours or practice counting in French. The first author did in fact observe Josie doing just that throughout his participant observation. There were only three toddlers registered, and she did indeed spend one-on-one time with each child.

Josie described the previous program model as being much more regimented and prescriptive. There were fewer opportunities for children to pursue their own interests and explore because the éducatrices directed almost all of the activities. Play time was restricted to around 10-15 minutes before the éducatrice would move on to the next activity. "Avant c'était les enfants qui choisissaient ce qu'ils voulaient jouer mais on donnait seulement quelques temps pour jouer. Ils n'avaient pas vraiment le droit de mélanger les jouets d'un coin à l'autre. Il fallait travailler toujours dans le coin qu'ils avaient choisi." ${ }^{\text {,vi }}$ If a child chose a particular toy or game, then he/she had a specific area in which to play. There were also limits to the number of children permitted to do a particular activity at one time. If the child wished to change activities, he/she would have to clean up his/her play area and then wait for an opening at the activity station that he/she wanted to use. In the new program, children were permitted to flow from one activity to the next without the same restrictions. Josie found that this created a less stressful, more peaceful environment for the children. In the nouveau programme, it was no longer the éducatrice's responsibility to direct all of the children's activities; instead, they had to find ways to fit teaching into the children's explorations and interests.

The two éducatrices responsible for the preschoolers were Monique and Karine. All three éducatrices were born and raised outside of Canada, though only two were Francophone. Monique and Karine were each responsible for a different group of preschoolers: Monique supervised the older group (3- and 4-year-olds), while Karine cared for the newer arrivals (2- and 3-year-olds) who had joined the preschool group two weeks earlier and were not yet accustomed to its daily routines.

Monique seemed to be more interactive with her group, who had been at the centre for a longer period of time and knew more French, during snack time. She asked 
them questions about colours and numbers, while Karine focused on short, polite requests connected to the snack. For example, Monique asked who in her group was wearing the colour pink, and the children responded with one-word answers (naming the correct child) whereas Karine reinforced expressions like, "Encore du lait?" and "Oui, s'il vous plaît.",vii

The children came from different ethnic backgrounds; some were visible minorities and others were of mixed racial backgrounds, as in many multicultural, English-medium ECEC settings in Canada. According to the éducatrices, most children were Anglophone. While one or two might occasionally speak French at home with their parents, the dominant home language was English. Conversations and interactions between the children in the ECEC setting took place entirely in English, except in the case of disagreements or arguments, at which point they would use the expression, "Non, merci!" For instance, if one child took a toy from another, the latter would say, "Non, merci!" and start to cry, leading an éducatrice to intervene and reinforce the concepts of sharing and turn-taking. The éducatrice would say, "On ne joue pas comme ça ici. On partage les jouets avec les amis". viii

Once the morning snack was finished, the children washed their hands and began playing with self-selected toys. Karine then cleaned up the tables that were colour-coded for the two groups of children while Monique circulated around the room, talking to them. She often asked, "Qu'est-ce que tu fais?"ix then re-stated the child's answer in French, as the answer was often given in English. Monique used these conversations to initiate teaching opportunities. For example, Monique approached a small group of children playing with letter blocks. After asking preliminary questions like, "Qu'est-ce que tu fais?", and re-stating the children's answers, "Oh! Tu joues avec les blocs!", she asked them to identify different letters on the blocks for her, then asked the colours of the letters. With each correct response, she praised the child by name and said, "Bravo!" She addressed incorrect responses immediately by introducing the correct answer and prompting the child to repeat it a few times. This repetition reinforced the correction and offered an opportunity to reinforce proper pronunciation while the integration of language features (e.g., vocabulary) into "content" (i.e., play in the ECEC context) also demonstrated Lyster's (2007) Counterbalanced Approach in action.

Monique then began implicitly introducing prépositions de lieu ${ }^{\mathrm{xi}}$ by using the blocks and a plastic bin to demonstrate devant, derrière, dans, and à côté de ${ }^{\text {iii }}$ She demonstrated this vocabulary several times, using different blocks, to show that the vocabulary was not specific to a particular block, but could be used for different ones.

The éducatrices implicitly introduced a variety of verb tenses (futur proche, l'imparfait, le présent, le passé composé, and l'impératifiii) to the children. Meal times were the examples most reminiscent of "content teaching". There were no anchor charts or white boards in the centre, but the children answered questions while they ate. For example, Monique asked the group seated around the blue table, "Qu'est-ce que tu vois dans la soupe?"xiv as she scooped a small carrot onto her spoon. With a little prompting from Monique, one child answered in English that it was a carrot. Monique re-stated the answer in French and emphasized, "On dit 'des carottes", xv The child repeated "des carottes", and Monique carried on, scooping different vegetables onto her spoon. This anecdote illustrates how the éducatrices integrated a focus on language forms into 
naturally occurring activities. Karine's focus in her group, which was new to the centre, was on short, polite requests for more milk, soup, or bread. She would say, "Veux-tu du pain?",xvi or "Encore du lait? Oui, s'il vous plaît”. xvii

Once lunch was over, the children were asked to go use the washroom, wash their hands, and return to their table groups. Monique cleaned the tables and placed a variety of French language books on them for the children. Soft instrumental music played in the background as they leafed through the books, looking at pictures. Monique circulated around the tables asking children about what they were reading and about specific pictures (e.g., asking them to identify colours, count animals, and identify different objects in the pictures). She made vocabulary salient and comprehensible during the activity. Once the cots were ready for nap time, Monique sang a different version of the clean-up song in French, to the tune of "Farmer in the Dell," and used variations of the song to give different instructions.

\section{The Use of Songs}

Overall, songs played a significant role in daily routines; they marked transitions, communicated instructions, and helped regulate behaviour. At snack or lunch time, the éducatrices sang the Bon appétit song to signal that it was time to begin eating ("Bon appétit les grands amis/ bon appétit les grands amis/ ça sera bon, hé! Ça sera bon, hé! Bon appétit les grands amis! Bon appétit les amis!"xviii). While the children were not prohibited from starting to eat during the song, they typically waited until it was finished. This song was sung daily.

The éducatrices signalled that it was time to clean up by standing up and calling out, "Statue! Statue les amis" and keeping their hands on their heads until the children had stopped their activities. They then sang the "clean-up song" (sung to the tune of "London Bridge"). ${ }^{\text {xix }}$ Whenever they were expected to stop and clean up, one of the éducatrices, typically Monique, would begin singing the song. It signaled to the children that play time was over and that they would be moving on to a different activity once the room was tidy. Specific songs were used to signal different major transitions (e.g., room clean-up, lining up at the door, and eating meals).

In addition to marking transitions, songs were used to engage the children's attention and reinforce teaching points. If they were noisy while waiting at the door to go outside, Monique or Stephanie would start singing some of the children's favourite songs (e.g., the Petit escargot ${ }^{x x}$ song: Petit escargot/ portait sur son dos/ sa maisonette. Aussitôt qu'il pleut/ il est tout heureux. Il sort sa tête. COUCOU! $\left.{ }^{x i}\right)$. If they were at their tables when the song began, the children knew to put down their heads, cover them up with their hands, and pretend that they were the little snail hiding under his shell. At the end of the song, the children would pop their heads back up and say, "Cuckoo!" Then they would call out, "Encore! Encore!" and sing the song again. By the third time through, the children would be calm and content.

Several songs reinforced colours, the most popular being the Papillon ${ }^{x x i i}$. The éducatrice would choose a child in the group and use his/her name in the song. At the end, the éducatrice would ask the child what colour his/her shirt was, or about different articles of clothing, depending on the vocabulary being reinforced. The song was repeated several times to give multiple children the opportunity to answer. ${ }^{\text {xiii }}$ Monique 
also used another song to reinforce colours with the children and encourage them to dance around and enjoy themselves. One day, when children were dressing up in costumes, Monique noticed that a child named Brandon had put on a multi-coloured grass skirt. After she asked him, "Veux-tu danser avec Monique?"xxiv, he took her hands and they began to dance around while she sang, "Brandon portait bleu, bleu, bleu. Brandon portait bleu/ toute la journée. Danse, danse, danse Brandon! Danse, danse, danse Brandon! Danse, danse, danse Brandon/ toute la journée!" "xv Once she finished the song, she asked who would like to dance next. Brandon took off the grass skirt and, as each of the children put it on, Josie asked them what colour they were wearing and went through the song again. By the end, all of the children were dancing around with her. She had repeated the process until every child who wanted to dance had had the opportunity to do so.

The éducatrices also sang songs to reinforce the letters of the alphabet, to count from one to five (or higher, depending on the child), and to name the parts of the body, members of the family, or different animals. Songs were often sung multiple times, allowing the children to practice the vocabulary over and over again in an active, entertaining manner. Gestures often accompanied the lyrics, which provided a way for children who did not know the words yet to participate as well.

\section{"At the Supermarket"}

A make-believe supermarket was an important activity centre in the preschool room of the child care centre. Early in the observation period, Monique spent several days cutting boxes in half, painting them brown to look like wooden crates, and gathering items to be "sold" during the activity. Photographs of individual fruits and vegetables were attached to boxes, which also contained plastic fruits and vegetables. While there were not enough plastic items to fill each box with the exact fruit or vegetable depicted in the photograph on the box, care was taken to separate the food appropriately (e.g., tomatoes were not placed with broccoli). In the days leading up to the launch of the activity, Monique asked parents to bring in empty cereal boxes, plastic bottles, egg cartons, and similar containers to stock the shelves of the supermarket. The final product resembled a small, downtown, storefront market.

A table with a toy cash register was set up to the side of the supermarket display near the kitchen/house play set. Beside the cereal boxes were small shopping baskets. Play money was placed in the baskets for the children to use during their trip to the market. Monique played the role of cashier as each child took turns filling a shopping basket and checking out. At the checkout, children were asked to put their groceries on the counter and Monique would ask them to identify what they had bought. She would pick up a piece of plastic fruit or vegetable and ask the child what it was called, repeating its name in French as necessary and prompting the child to repeat it back to her. Next, she would ask the child to identify the item's colour. Again, Monique would repeat the name in French and prompt the child to do the same. Finally, she would ask the child to count the number of items he/she was purchasing. In some cases, Monique also requested that children count how many vegetables they had bought or all the items that shared a particular colour (e.g., green). She geared her questions to individual children's level of 
French fluency by asking those who had been in the centre the longest more detailed questions than recent arrivals.

At first, the supermarket was more popular with girls than boys; however, it soon became a daily staple of all the children's activities. In keeping with the principles of the Emergent Curriculum, no formal time was set aside to use the supermarket. The materials were always on display and the children had an open invitation to go "shopping" whenever they had free playtime. Whenever Monique noticed that children had begun "shopping", she would assume her position at the cash register.

\section{Discussion}

The general pedagogy employed at the child care centre is deeply rooted in the Emergent Curriculum and interaction/experiential approaches to pedagogy, and it follows that the developmental FFL/L2 focus is thus situated in child-directed learning that allows them to follow their own interests as well. In keeping with the Emergent Curriculum, the éducatrices seize the teachable moments provided by the children. To the casual observer, the Emergent Curriculum approach may seem disorganized and chaotic; however, if done properly, as the supermarket activity illustrates, it engages children and makes learning relevant to their own experiences. Similarly, there is a counterbalanced (i.e., motivational, purposeful) approach to children's (FFL/L2) engagement with language.

The teaching that takes place in the centre is informal and natural. There are no anchor charts or white boards. The closest centre activities get to formal classroom instruction is during meal time when children gather together at the red and blue tables, reminiscent of what one might see during a Guided Reading session in an elementary school. In the latter setting, student reading groups gather with their teacher around a crescent moon-shaped table during Guided Reading sessions to read through a book or short story together and respond to teacher-initiated questions. In this child care centre, the children gathered around a crescent moon-shaped table to eat their meals and respond to questions initiated by the éducatrice; however, the teaching that goes on during meal time is still very informal. The children are engaged in eating, making the mini-lessons seem like casual meal-time conversations. Also, since the mini-lessons were almost always connected to language learning and vocabulary building, their integration (as "teaching") into meal times constituted instantiations of Lyster's (2007) Counterbalanced Approach to children learning language through content. ${ }^{\text {xxi }}$

Positive reinforcement and encouragement are key components of the pedagogical style employed by the éducatrices in the centre. Correct responses are met with words like "Bravo", while incorrect responses are met with follow-up questions to try to prompt correct answers. At no point do the éducatrices tell the children that they are wrong or incorrect - there is no shame, embarrassment, or judgement connected with wrong answers (or linguistic forms). They simply support the child and give him/her the opportunity to give answers that are correct in terms of content; they are given the opportunity to produce French (as L1 or L2) that is appropriate to their individual level of language development. The children are made to feel safe as they learn to communicate. This reinforcement encourages and empowers children to take "risks" in their L2, which positively reflects Cummins' (2009) perspective on pedagogy and Lyster's (2007) 
emphasis on young children being offered opportunities to interact throughout the course of purposeful L2 learning (and gaining cognitive/linguistic skills in/through FFL as well).

The Emergent Curriculum used in this child care setting complements Lyster's (2007) Counterbalanced Approach at an age-appropriate level. The children were actively engaged in play activities that acted as entry points for the éducatrices to provide content and language instruction. They integrated language learning into play activities, shifting the children's attention from what they were doing on to French vocabulary, thus "counterbalancing" the activity. While Lyster intended his framework to be used with older children in academic content-based classes, the findings in this study demonstrate its applications with younger children. The supermarket activity, in particular, is an excellent example of the Counterbalanced Approach in action. All of Monique's interactions with the children during this activity can be seen as evidence of Lyster's (2007) approach due to the way she integrates vocabulary-building and reinforcement into the role-playing activity. The supermarket activity was grounded in everyday experiences the children were likely to have with their parents and in the community; it offered an authentic, realistic opportunity to learn vocabulary in a meaningful way and, since Monique was already participating in the activity as the cashier, her questions did not intrude on the children's enjoyment. It also offered many entry points to reinforce French language learning. In addition to teaching colours, counting, and the names of food items, Monique had the option to integrate size comparisons (big or small) and the sorting of items according to colour or type, with possibilities continuing to grow as more items were added.

Similar to findings by Björklund, Mård-Miettinen, and Savijärvi (2014), Taylor (1992 \& 1998), Weber and Tardif (1990), routines became important parts of the French language learning environment in this study as well. The consistency of the routines created a sense of stability for the children, which was important to the effectiveness of the overall environment for learning French. Routines were particularly important for newcomers at Karine's red table group, with songs and gestures providing an entry point for making sense of activities. For example, once Monique began singing the clean-up song, they knew it was time to put the toys away and then go to the washroom. If she had just called out instructions, they may have just continued playing. The routines and gestures augmented the children's understanding beyond their current language levels.

\section{Conclusion}

The éducatrices in the centre use every activity as an opportunity for French language instruction. By incorporating the children's interests in an Emergent Curriculum and interaction/experiential pedagogical approach, vocabulary and grammatical concepts are introduced and reinforced. This integration of language into activities comes across so naturally that the children may not even realize that language is being taught to them. Language instruction, though very informal, is central to the centre's daily routines. Even an activity as simple as playing with coloured letter blocks provides a language learning opportunity (e.g., practicing identifying letters and colours). This manner of introducing vocabulary and language features into everyday play activities and games demonstrates an age-appropriate application of Lyster's (2007) Counterbalanced Approach to second 
language instruction. The language features taught are relevant to the children and rooted in their everyday experiences.

Specific supports for Anglophone and allophone children were difficult to distinguish because only two children spoke French as their first language. Language instruction was presented by way of routines accompanied by gestures, demonstrations, and repetition, and children were praised for properly interpreting instructions and using new expressions. The éducatrices built up vocabulary incrementally; they recognized that children were progressing at their own pace regardless of their L1 and that patience is required when teaching preschoolers a new (or developing) language. As such, the éducatrices met the needs of the FFL, Anglophone, and allophone children. Future longitudinal research is needed to gain further insight into how these two preschool groups and the toddler group will fare with the literacy demands of the K-6 FFL school system, the impact that being immersed in ECEC settings with non-Francophones has on the Franco-Ontarian mission of the centres, or whether the centres meet FFL children's French literacy needs nonetheless. However, the results of this study suggest that the FL needs of non-Francophone children were met in the Franco-Ontarian ECEC centre described in this study.

\section{References}

Björklund, S., Mård-Miettinen, K., \& Savijärvi, M. (2014). Swedish immersion in the early years in Finland. International Journal of Bilingual Education and Bilingualism, 17(2), 197-214. Retrieved from http://dx.doi.org/10.1080/13670050.2013.866628

Canadian Language and Literacy Research Network/CLR-net. (2009). National strategy for early literacy: Reports and recommendations. London, ON: Canadian Language and Literacy Research Network at the University of Western Ontario. Retrieved from http://eyeonkids.ca/docs/files/national strategy for early literacy report $\% 5 \mathrm{~B} 1 \% 5 \mathrm{D}$. pdf

Cormier, M., Bourque, J., \& Jolicoeur, M. (2014). (Re)-introduction to French: four education models to revitalise an endangered group in Eastern Canada. International Journal of Bilingual Education and Bilingualism, 17(2), 160-177. Retrieved from http://dx.doi.org/10.1080/13670050.2013.866626

Cummins, J. (1989). Empowering minority students. Sacramento, CA: California Association for Bilingual Education.

Cummins, J. (1997). Minority status and schooling in Canada. Anthropology \& Education Quarterly, 28(3), 411-430.

Cummins, J. (2001). Empowering minority students: A framework for intervention. Harvard Educational Review Classic reprint. Harvard Educational Review, 71(4), 656-675.

Cummins, J. (2009). Transformative multiliteracies pedagogy: School-based strategies for closing the achievement gap. Multiple Voices for Ethnically Diverse Exceptional Learners, 11(2), 1-19.

Dubinski, K. (2012, May 23). Parents want third French school. The London Free Press. Retrieved from http://www.lfpress.com/news/london/2012/05/22/19787776.html. 
École Frère-André. (n. d.). Plan d'amélioration du rendement des élèves M-12. École Frère-André. Retrieved from http://www.csdecso.on.ca/Ecoles/FrereAndre/media/profil.pdf.

École Pavillon-des-Jeunes. (n. d.). Plan d'amélioration du rendement des élèves M-12. École Pavillon-des-Jeunes. Retrieved from http://www.csdecso.on.ca/Ecoles/Pavillon-des-jeunes/media/profil.pdf.

École Saint-Jean-de-Brébeuf. (n. d.). Plan d'amélioration du rendement des élèves M-12. École Saint-Jean-de-Brébeuf. Retrieved from http://www.csdecso.on.ca/Ecoles/StJean-de-Brebeuf/accueil.html.

École Saint-Michel. (2011). Plan d'amélioration du rendement des élèves M-12. École Saint-Michel. Retrieved from http://www.csdecso.on.ca/Ecoles/StMichel/media/profil.pdf.

École Saint-Paul. (n. d.). Plan d'amélioration du rendement des élèves M-8. École SaintPaul. Retrieved from http://www.csdecso.on.ca/Ecoles/St-Paul/media/profil.pdf.

École Saint-Philippe. (n. d.). Plan d'amélioration du rendement des élèves M-12. École Saint-Philippe. Retrieved from http://www.csdecso.on.ca/Ecoles/StPhilippe/media/profil.pdf.

École Sainte-Jeanne-d'Arc. (n. d.). Plan d'amélioration du rendement des élèves M-12. École Sainte-Jeanne-d'Arc. Retrieved from http://www.csdecso.on.ca/Ecoles/SteJeanne-d_Arc/media/plan.pdf.

Éducation en langue française en Ontario. (n. d.) Find an institution - FLE. Retrieved from http://www.elfontario.ca/en/elementary-schools.php.

Gérin-Lajoie, D. (2003). Parcours identitaires de jeunes francophones en milieu minoritaire. Sudbury, ON : Les Éditions Prise de parole.

Government of Alberta. (2009). Living literacy: A literary framework for Alberta's next generation economy. Edmonton, AB: Government of Alberta. Retrieved from http://eae.alberta.ca/media/219400/living\%20literacy.pdf

Government of Canada. (1982). Section 23: Minority language educational rights. Constitution Act. Retrieved from http://laws-lois.justice.gc.ca/eng/Const/page-15.html

Government of Canada. (2008). Roadmap for Canada's linguistic duality 2008-2013: Acting for the future. Ottawa, ON: Government of Canada.

Government of Canada. (2012). Roadmap for Canada's linguistic duality 2008-2013: Acting for the future. Mid-term report. Ottawa, ON: Government of Canada.

Hébert, M. \& Lafontaine, L. (2010). Pratiques et outils pédagogiques en littératie dans une perspective d'inclusion. Québec, QC : Presses de l'Université du Québec.

Heller, M. (1999/2006). Linguistic minorities and modernity: A sociolinguistic ethnography. London, Great-Britain: Continuum International.

Heller, M. (1994/2003). Crosswords: Language, education and ethnicity in French Ontario. Berlin, Germany: Mouton de Gruyter.

Jones, E. (2012). The emergence of emergent curriculum. YC Young Children, 67(2), 6668.

Lyster, R. (2007). Learning and teaching languages through content: A counterbalanced approach. Amsterdam, Netherlands: John Benjamins. 
Lyster, R. (2008). Evolving perspectives on learning French as a second language through immersion. In D. Ayoun (Ed.), Studies in French Applied Linguistics (pp. 336). Amsterdam, Netherlands : John Benjamins.

Ministère de l'éducation. (2004). Politique de l'aménagement linguistique de l'Ontario : pour l'éducation en langue française. Retrieved from http://www.edu.gov.on.ca/fre/document/policy/linguistique/linguistique.pdf

Ontario Ministry of Children and Youth Services. (2007). Early learning for every child today: A framework for early childhood settings; Best start expert panel on early learning, January 2007. Toronto, ON: Government of Ontario.

Ontario Ministry of Education/MEO. (2005). Education for all. Toronto, ON: Government of Ontario. Retrieved from http://www.edu.gov.on.ca/eng/document/reports/speced/panel/speced.pdf

Ontario Office of Francophone Affairs \& The Ontario Trillium Foundation. (2009). Profile of Ontario's francophone community 2009. Toronto, ON: Government of Ontario. Retrieved from http://docs.files.ontario.ca/documents/409/francophoneprofile.pdf

Princess Anne French Immersion P.S. (n. d.). About us. Princess Anne French Immersion P.S. (London). Retrieved from http://www.tvdsb.ca/Princess Anne.cfm? subpage $=444$ on July 23, 2012.

Russette, A. (2013). A case study of pedagogical practices and learning environment in an Ontario Francophone child care centre. (Unpublished Master's thesis). The University of Western Ontario.

Skutnabb-Kangas, T. (2000). Linguistic genocide in education: or worldwide diversity and human rights? Mahwah, NJ: Lawrence Erlbaum.

Statistics Canada. (2007). 2006 Census of population. Statistics Canada Catalogue no. 97-555-XCB2006031 (Windsor, Code559). Ottawa, ON: Canada.

Statistics Canada. (2007). 2006 Census of population. Statistics Canada Catalogue no. 97-555-XCB2006046 (London, CY, Code3539036). Ottawa, ON: Canada.

Statistics Canada. (2007). London, Ontario (Code3539036) (table). 2006 Community Profiles. 2006 Census. Statistics Canada Catalogue no. 92-591-XWE. Ottawa, ON: Canada. Retrieved from http:/www12.statcan.ca/census-recensement/2006/dp$\mathrm{pd} /$ prof/92-591/index.cfm?Lang=E

Statistics Canada. (2007). Windsor, Ontario (Code559) (table). 2006 Community Profiles. 2006 Census. Statistics Canada Catalogue no. 92-591-XWE. Ottawa, ON : Canada. Retrieved from http://www12.statcan.ca/censusrecensement/2006/dp-pd/prof/92591/index.cfm?Lang=E

Swain, M., \& Lapkin, S. (1982). Evaluating bilingual education: A Canadian case study. Clevedon, England: Multilingual Matters.

Taylor, S. (1992). Victor: A case study of a Cantonese child in early French immersion. The Canadian Modern Language Review, 48(4), 736-759.

Taylor, S. K. (1998). Beyond 'belief': Variance in models of content-based instruction and school success among minority language learners. Bulletin suisse de linguistique appliquée (Swiss Review of Applied Linguistics)/VALS (ASLA), 67, pp. 61-83. 
Weber, S., \& Tardif, C. (1990). The young child's view of starting French immersion. In B. Fleming \& M. Whitla (Eds.), So you want your child to learn French $\left(2^{\text {nd }}\right.$ ed., pp. 54-66). Ottawa, ON: Canadian Parents for French.

\section{Author Biographies}

Alan D. Russette is a doctoral candidate in the Faculty of Education at Western University. His research focus is on pedagogy and learning environments in French First Language and French as a Second Language elementary schools.

Dr. Shelley K. Taylor is an Associate Professor in the Faculty of Education at Western University. Her research focus is on how linguistic minority children fare in bilingual education programs designed for majority group populations.

\footnotetext{
${ }^{\mathrm{i}}$ Canada has two official languages: English and French. The French-speaking population resides primarily in the province of Quebec and parts of New Brunswick, though there are pockets of Francophones spread throughout the country. People living in these areas are considered members of Official Language Minority Communities. Similarly, Anglophones living in Quebec are considered an Official Language Minority Community. Speakers of any language other than English or French are not considered part of an Official Language Minority Community.

${ }^{\text {ii }}$ See Skutnabb-Kangas (2000).

iii See also Hébert \& Lafontaine (2010) and Heller (1999/2006).

${ }^{\text {iv }}$ Pseudonyms are used for all the participants for purposes of anonymity.

"Le nouveau programme translates as "the new program". The old program was referred to as "l'ancien programme".

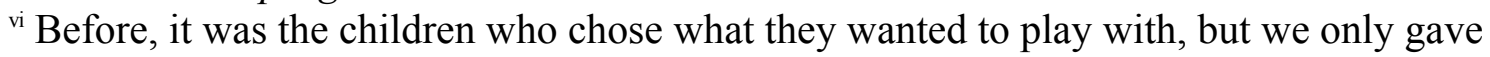
them a bit of time to play. They didn't really have the right to mix and move the toys from one corner to another. They always had to stay in the corner they had chosen. vii "Would you like more milk?" and "Yes, please"].

viii "We don't play like that here. We share the toys with friends."

ix "What are you doing?"

x "What are you doing?"

xi Place prepositions.

${ }^{x i i}$ In front of, behind, in, and beside.

${ }^{\text {xiii }}$ Near future, imperfect, present, past, and imperative tenses.

xiv "What do you see in the soup?"

xv "We say, "Carrots".

xvi "Would you like some bread?"

xvii "More milk? Yes, please."

${ }^{\text {xviii }}$ Pick up the books, pick up the books. Oh yeah oh yeah oh yeah, pick up the books.

${ }^{x i x} C$ 'est le temps de tout ranger, ramasser, nettoyer. C'est le temps de tout ranger. À la [name of the child care centre]. Rangez vite et rangez bien, ramassez, nettoyez. Rangez vite et rangez bien. Tous les beaux jouets. [It's time to tidy up, pick up, and clean
} 
everything. It's time to tidy up everything/ at the child care. Tidy up quickly, tidy up well, pick up and clean. All the beautiful toys].

${ }^{\mathrm{xx}}$ Little snail

${ }^{x x i}$ Little snail/ wore on his back/ his house. As soon as it rains/ he is really happy. He pops out his head. Cuckoo!

xxii Butterfly

xxiii The general song lyrics were: Avez-vous vu un papillon? Un papillon, un papillon? Avez-vous vu un papillon/ sur la tête de [child's name]? C'est quoi la couleur de ton chandail? [Have you seen a butterfly? A butterfly, a butterfly? Have you seen a butterfly/ on [child's name]'s head? What colour is your shirt?]

xxiv "Do you want to dance with Monique?"

xxv "Brandon was wearing blue, blue, blue. Brandon was wearing blue/ all day long. Dance, dance, dance Brandon! Dance, dance, dance, Brandon! Dance, dance, dance, Brandon/ all day long! »

${ }^{x x v i}$ While this serves as a clear example of the link between Lyster's (2007) counterbalanced approach to teaching language through content, it was not intentional on the part of the éducatrices as they were unfamiliar with his work. 